\begin{tabular}{l} 
SCIENCE \& TECHNOLOGY \\
Journal homepage: http://www.pertanika.upm.edu.my/ \\
\hline PERTANIKA
\end{tabular}

\title{
Factors in Adopting Green Information Technology: A Qualitative Study in Malaysia
}

\author{
Siti Aishah Ramli ${ }^{1 *}$, Boon Cheong Chew ${ }^{1}$ and Adi Saptari ${ }^{2}$ \\ ${ }^{\prime}$ Faculty Of Technology Management and Technopreneurship, Universiti Teknikal Malaysia Melaka, Hang \\ Tuah Jaya, Durian Tunggal, 76100 Melaka, Malaysia \\ ${ }^{2}$ Department Of Industrial Engineering, President University, Ji. Ki Hajar Dewantara, Kota Jababeka, Cikarang \\ Baru, Bekasi 17550, Indonesia
}

\begin{abstract}
Green Information Technology (IT) has emerged as a crucial topic for environmentally and sustainability development. At the same time, Green IT impacts the organisation as well. Studies show there is a lack of a proposed framework in the Green IT literature. As the IT industry is one of the significant sectors supporting the Green Technology Policy, this study objective is to identify the factors rendered in the Green IT adoption and examine the factors that drive the adoption of Green IT in Malaysia. The study referred to the case study to show the most important factors rendered in Green IT adoption in the public sector and the private sector in Malaysia. A qualitative method was applied through a semi-structured interview by using open-ended questions as a guideline with five organisations from the public sector and the private sector. This study prioritises the explanation building as a specific approach to analysis. Results show that there are five factors rendered in Green IT adoption in Malaysia: environmental factor, cost factor, organisational factor, technological factor, and business opportunity factor. This study benefits policymaker, organisations, and other researchers to support Malaysia's pledge to reduce its Greenhouse Gas (GHG) emission intensity of Gross Domestic Product (GDP) by up to 45\% by 2030 .
\end{abstract}

ARTICLE INFO

Article history:

Received: 25 December 2020

Accepted: 01 April 2021

Published: 31 July 2021

DOI: https://doi.org/10.47836/pjst.29.3.12

E-mail addresses:

sitiaishahramli@hotmail.com (Siti Aishah Ramli)

bcchew@utem.edu.my (Boon Cheong Chew)

adi.saptari@president.ac.id (Adi Saptari)

* Corresponding author
Keywords: Green and sustainable practices, green IT, Malaysia

\section{INTRODUCTION}

Green IT has been discussed in many aspects nowadays towards reducing the global carbon emission produced by IT consumptions. In Malaysia, Green IT is considered new to implement. The National 
Green Technology Policy was established in Malaysia in 2009 and addresses five strategic thrusts. One of the strategies is to strengthen efforts in promotion and improve the awareness of people in ICT technology (Ministry of Energy, Green Technology and Water of Malaysia, 2009). The $6^{\text {th }}$ Malaysian Prime Minister indicates:

"Green Technology is a blue ocean strategy as it transcends across all sectors of the economy. It provides vast opportunities for government and business to innovate and grow as well as developing new parts of competitiveness" (Kasbun et al., 2016).

Thus, the National Green Technology Policy establishment strengthening the new green ideas for the ICT sector (GreenTech, 2011).

Rad et al. (2018) reported that there is a lack of study in technology adoption. Studies show that there are organisations in the government sector that emphasise environmental aspects in Green IT adoption (Junior et al., 2018). While several past studies briefly discussing Green IT adoption in the Malaysia organisation. Rahim \& Rahman (2013) briefly discussed the Green IT capabilities and resources in the Malaysia public listed organisation; Esfahani et al. (2015) generally revised the importance of motivational in Green IT implementation in the organisation. Therefore, this study focusses on two objectives. First, to examine the most important factors rendered the Green IT adoption by MAMPU, KeTTHA, GreenTech Malaysia, International Business Machine (IBM) Malaysia and Hewlett-Packard (HP) Malaysia and second, is to propose a framework in implementing the Green IT.

\section{Green IT in Malaysia}

The key landmark for the ICT industry in Malaysia started in 1997 when the Multimedia Super Corridor (MSC) Malaysia becomes the national agenda for the nation's development. In July 2009, the National Green Technology Policy (NGTP) was established with a policy statement which is "green technology shall be a driver to accelerate the national economy and promote sustainable development" (GreenTech, 2013). The NGTP outlined five strategic thrusts: i) Strengthen the Institutional Frameworks, ii) Provide a Conducive Environment for Green Technology Development, iii) Intensify Human Capital Development in Green Technology, iv) Intensify Green Technology Research and Innovations and v) Promotion and public awareness. Follows by four pillars in energy, environment, economy and social and focus on six sectors including energy, water, waste, building, manufacturing, and transport (Ministry of Energy Green Technology and Water, 2017). Thus, to achieve the NGTP objective, this study focus on Green ICT Malaysia covers the term of adoption, and factors, as the preparation which directly leads to in-depth understanding and finally able to propose a framework that can be used to ensure the widespread adoption of Green IT in Malaysia. 


\section{Technology Adoption Models}

This study applies two models - Technology-Organisation-Environment (TOE) and Diffusion of Innovation (DOI). TOE model explains the organisational adoption and execution of technological innovation. This model is recognised as determining factors of organisation level innovation adoption (Cobos et al., 2016; Zhang et al., 2020). Whilst DOI examines innovation adoption from a process perspective (Cobos et al., 2016). TOE is consistent with DOI as both theories recognised as determining factors of organisational level in innovation adoption. For instance, DOI's innovative characteristics and internal and external characteristics of the adopting organisation are accordances with the TOE framework's innovation and organisational contexts (Cobos et al., 2016; Asadi et al., 2017). Besides, TOE and DOI models are aligned to apply in the qualitative method which the researcher conducts this study through a semi-structured interview. From there, the researcher able to find which factors are important in the adoption of Green IT in Malaysia. Besides, through the TOE and DOI framework, the researcher able to apply the models as a guideline in determining the factors that rendered Green IT adoption and place the TOE models factor as the main factor. Therefore, TOE and DOI models are relevant to this study. These models are applied to investigate the factors rendered in Green IT adoption and how the Green IT technology diffused in the organisations.

\section{Green Information Technology (IT)}

According to Asadi et al. (2019), the concept of Green IT is affected by and related to sustainability, ecological sustainability, information systems, and information technology concepts. In the meantime, many scholars express Green IT terminologies with green computing, environmentally, sustainable computing, and energy efficiency based on their perspective of business concern and organisation operation. Dalvi-Esfahani et al. (2020) defined Green IT as the process of manufacturing, using, and disposing of all related IT (hardware and software) concerning eco-friendly issues. The definition focuses on both enhancing energy efficiency and intensifying the sustainability of the environment by reducing the pollution released from IT hardware and software. Besides, it is also an example of a green growth initiative pointed at enhancing performance and productivity through sustainable utilization and production of organisational and societal resources (Gazzola et al. 2018). Therefore, this study focuses on Green Information Communication Technology to examine the factors that rendered the Green IT adoption in Malaysia.

\section{The Factors Rendered Green IT Adoption}

There are seven factors discusses in Green IT adoption. The factors identify the Green IT adoption based on literature in Malaysia organisation.-Below explain the details. 
Technological Factor. Unhelkar (2016) points out that there are two primary technologies in Green IT which are hardware within the organisation and application. De Zoysa and Wijayanayake (2013) illustrate more on the technology areas of Green IT includes the data centre, virtualization, utilization, storage area network and the other application. However, as Green IT adoption possess various scope in the technology aspect, the wide ranges of technical aspects related to design, manufacture, use, and disposal of Green IT technologies are focused. However, most of the studies records technological factor are not tend to organisation studies. For instance, consumers' intention toward adoption of vehicle (Asadi et al., 2020); green fertiliser technology through farmers behaviour (Adnan et al., 2019); green building sector (Azis, 2021) and the awareness of solar energy technology among households (Malik \& Ayop, 2020).

Competitive Pressure Factor. Referring to De Zoysa and Wijayanayake (2013), the organisation may feel the pressure from competitors in the same industry, which comes from strong company's background to keep their image. This means when a competitor's products or services are better than our company, we will feel the pressure that our profits will decrease. Simon (2013) expresses that one of the key drivers of successful technology development and adoption is a market formation which is developing marketplace by developing new products and services, identify customer and users' needs, develop viable business models, consider possibilities for exports, and needs for imports. Therefore, companies should adopt technological tools to meet certain demands in the market (Khan \& Faizal, 2015).

Organisational Factor. Dash et al. (2016) demonstrate that every organisation pursues to improve their business operation which includes the necessity of strategic planning to adopt new technology in establishing several process stages to improve the organisation performance. In Malaysia organisation, study shows that there is a relationship between Green IT attitude and engagement in support green computing practices (Ojo et al., 2019). Letlonkane and Mavetera (2014) emphasize that top management, such as Chief Information Officer and IT managers have an optimistic attitude on the advantage of adopting Green IT to the organisation. Besides, Molla and Abareshi (2014) examine that actions undertaken by senior management can introduce complementary structures to assist learning and innovation.

Environment Factor. According to Fernando and Wah (2017), environment performance in organisation processes to achieve firms goals for environmental improvement and gas emission reduction in Malaysia. Shameer et al. (2015) highlight that Green IT is the solution concerned with reducing the environmental impact of IT before IT devices are purchased, during their lifetimes and after consumers have finished with them. Given the example of 
environmental performance in an organisation, Saha (2014) mentions that electricity is a crucial cause of climate change as the thermal power plants that aid generates electricity also releases a high amount of carbon dioxide and many other harmful particles into the atmosphere. As we know that the consumption of IT generated by electricity, Lee et al. (2013) examine that IT products consume considerable amounts of energy, contributing to the emission throughout their entire life cycle, from production to use and disposal. Shibly (2015) supports that most of the components discovered in prevalent computers are not only harmful to the environment but potentially harmful to human health. However, Asadi et al. (2020) reports that there is still a lack of green initiatives study relates to the environment in Malaysia organisation.

Regulatory Support Factor. According to Zailani et al. (2015) illustrate that the involvement in environmental protection obliged through legal regulations. Taruna et al. (2014) examine that one of the strategies regarding the adoption of Green IT is being as such the countries, especially emphasizing toward the developing countries must have to go through the policies strictly or to adopt Green IT policy seriously. This stated in Unhelkar (2016) indicates that some governments are forcing companies to make a report on their carbon emission every year. Therefore, Murugesan and Gangadharan (2012) highlight that this will bring towards the success of Green IT adoption and implementation and it will confirm the reduction of the carbon footprint from the organisations. This is supported by Mergel and Bretschneider (2013) emphasize where the organisation may follow the regulation to avoid the penalties and other taxes.

Business Opportunity Factor. Singh and Vatta (2016) mention that opportunities in green technology ordain like never in history and organisations are looking at it as a technique to generate new profit centres while trying to support the environment. Unhelkar (2016) claims that the adoption of Green IT provides the opportunity for the organisation to offer product or services to the other organisation at the same time achieve green initiatives and goals. Moreover, Gupta and Kumar (2012) emphasize that major IT companies are already applying green standards to their operations to gain new revenue opportunities and promote social and environmental responsibility influencing customers and market competition. Besides the development of policies and the provision of supervisory support, Lee et al. (2013) state that overseas governments have proactively taken the lead concerning Green IT and technology initiatives by funding R\&D collaboration between the government, academia, and industry, and offering incentives for deployment.

Cost Factor. Referring to Chen and Ma (2014) and Dibra (2015), claim that cost is one of the factors in the adoption of new technology. In implementing the new technologies, especially in green technology, the start-up cost was high, but the government believed that 
the maintenance costs would be low in the long run, making the technologies cost-effective (Managi et al., 2014). De Zoysa and Wijayanayake (2013) pointed out that even though the time taken to reach breakeven is high, however, government incentives may contribute to the value proposition, and new challenges will come up as new technology, skills, and process changes. Plus, Mohammed et al. (2015) illustrate that the adoption of Green IT is a significant saving in the product costs by utilizing resources efficiently.

\section{Theoretical Framework}

The theoretical framework is constructed as a guide for the entire process in this case study. Figure 1 shows the theoretical framework of Green IT adoption based on the collected secondary data from the academic scholar about technology adoption and Green IT. It is formulated to explain, predict, and understand phenomena and to challenge and extend existing knowledge within the limits of critical bounding assumption. The theoretical framework in this case study consists of seven factors which is Technological Factor, Organisational Factor, Environmental Factor, Regulatory Support Factor, Competitive Pressure Factor, Business Opportunity Factor, and Cost Factor. In each of the listed factors has further explanation enables to go in-depth about the research topic. Based on the theoretical framework, the elements guided the whole process for the adoption of Green IT in Malaysia in term of management. As shown in Figure 1, this study concluded that the theoretical framework was constructed based on the research objectives as the research objective is to examine the factors rendered in Green IT adoption and the proposed framework in Green IT adoption. Thus, based on this theoretical framework, the researcher is able to conduct semistructured interviews to test this theory in order to gain the outcome and finally will be able to propose new framework.

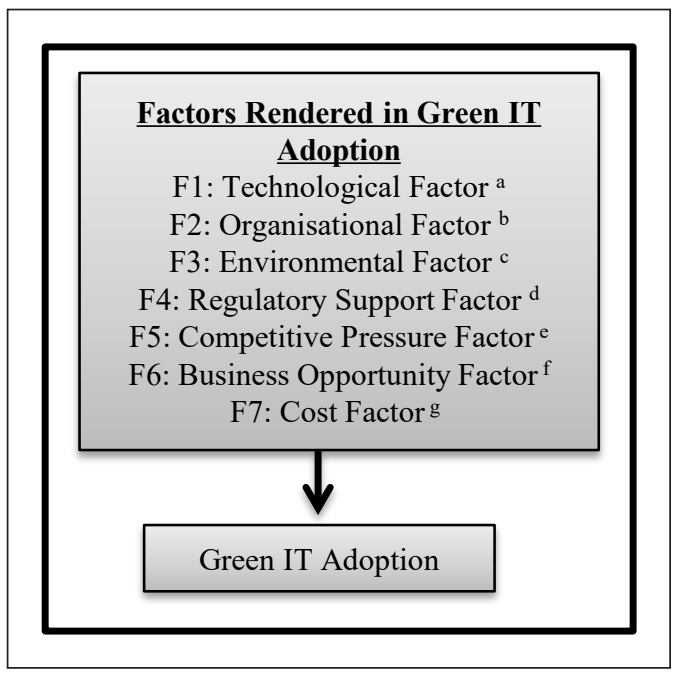

Figure 1. Theoretical framework

\section{MATERIALS AND METHODS}

This study is conducted qualitatively in semi-structured interviews and a purposive sampling approach. The 23 respondents participate in these interviews with open-ended questions (six respondents from KeTTHA, six respondents from MAMPU, one respondent from GreenTech Malaysia, six respondents from IBM Malaysia and four respondents from HP Malaysia). The respondents are a policymaker, ICT coordinator, execution of Green 
Technology Policy and IT producers. Purposive sampling or judgmental sampling was applied in collecting the data following the opinion of an expert in a particular field is the topic of interest (Martínez-Mesa et al., 2016). This study, specifically selected respondents from public and private company mentioned to contribute to the Green IT adoption topic and sharing their expert knowledge and experiences on the factors and the process of adopting Green IT in organizations. The 23 respondents are sufficient to represent this study as data reached a point of saturation which when the new themes stop emerges, the researcher can conclude that there is no need for more interviews (Saunders et al., 2016). Saunders et al. (2016) claimed that the minimum sample size for in-depth interview is $5-25$ respondents. Besides, at least 15 interviews were needed for the sample size requirement for all types of qualitative research (Guest et al., 2006). As a rule of thumb, it can be said that interview studies tend to have around 15 participants, which is a number that makes possible practical handling of the data (Brinkmann, 2013).

\section{RESULTS AND DISCUSSIONS}

\section{Technological Factor}

According to Shibly (2015) stated that technology is not a passive observer, but it is an active contributor in achieving the goals of Green IT. There are three criteria elaborate on the technological factor. First, the company following the trend and direction of technology; second is adopting IT software (green data centre, cloud computing, adopted virtualization of technology); and third is IT hardware (thin client which shared personal computer (PC) that has a small Central Processing Unit (CPU) and optimizing the use of CD, driver, and other hardware which at the end contribute to the electronic waste). Results show that 14 out of 16 respondents agreed technological factor is one of the factors in adopting Green IT. One of the respondents from KeTTHA quotes that

"...Technology is always coming and we need to pursue the technology".

One of the Respondents from MAMPU agrees that:

"For Green IT technology, the company is constantly looking at new technologies and alerts about the latest technology to support the reduction of carbon emission.

One of the respondents from Green Tech said that:

"The technology that's appropriate, fulfilling the desired green requirements, will be adopted into the organisation".

Thus, the similarities public and private sector is the adoption the latest technology such as cloud, green data centre, and virtualization, shared the same views regarding the 
technologies are growing over time and they took as an advantage to their organisation to improve the technologies in the organisation. Plus, four respondents from IBM Malaysia and HP Malaysia agree that must grab the new technologies as an opportunity to develop the new products and services to meet the customer expectation based on the circulation of time. One of the respondents from the Company stated that:

“...HP Malaysia is always looking for growth technologies which able to meet the customer expectation at the same time contribute to the eco-friendly by manufacturing a new product which minimizes the use of hazardous materials and fulfils the global requirements".

Table 1 simplify the result.

Table 1

Technological factor in Green IT adoption

\begin{tabular}{|c|c|c|}
\hline $\begin{array}{l}\text { Technological } \\
\text { factor criteria }\end{array}$ & Result from Public Company & Result from Private Company \\
\hline $\begin{array}{l}\text { Follow the trend } \\
\text { and direction of } \\
\text { technology }\end{array}$ & $\begin{array}{l}\text { "Technology is always coming and we need to } \\
\text { pursue the technology" (Respondent from KeTTHA) }\end{array}$ & $\begin{array}{l}\text { "HP Malaysia is always looking } \\
\text { for growth technologies which } \\
\text { able to meet the customer }\end{array}$ \\
\hline $\begin{array}{l}\text { Adopting IT } \\
\text { software }\end{array}$ & $\begin{array}{l}\text { "For Green IT technology, the company is constantly } \\
\text { looking at new technologies and alerts about the } \\
\text { latest technology to support the reduction of carbon } \\
\text { emission (Respondent from MAMPU) }\end{array}$ & $\begin{array}{l}\text { expectation at the same time } \\
\text { contribute to the eco-friendly } \\
\text { by manufacturing a new } \\
\text { product which minimizes the }\end{array}$ \\
\hline \multirow[t]{2}{*}{ IT hardware } & \multirow{2}{*}{$\begin{array}{l}\text { "The technology that's appropriate, fulfilling the } \\
\text { desired green requirements, will be adopted into the } \\
\text { organisation" (Respondent from GreenTech) }\end{array}$} & $\begin{array}{l}\text { use of hazardous materials and } \\
\text { fulfils the global requirements", }\end{array}$ \\
\hline & & $\begin{array}{l}\text { (Respondent from } H P \\
\text { Malaysia) }\end{array}$ \\
\hline
\end{tabular}

\section{Organisational Factor}

There are six criteria in the organisational factor. First, responsible in developing country and plays its role with the nation as stated by Ministry of Energy, Green Technology and Water of Malaysia (2009) that Malaysia has taken serious steps in addressing global emissions problems by launching a program of National Green Technology Policy in 2009. Second criteria are based on three stages of adoption in government which is procurement side (match with a green aspect such as Energy Star, EPEAT), uses side (electric consumption on hardware such as PC, Monitor, server, printer, notebook, and the application) and disposal side (follow government disposal procedure asset 2007). Third, forced by Green Technology Policy and IT as an initiative to develop Green IT. Fourth is top management support to make the organisation a role model or benchmark. The fifth is improving the environmental performance and sixth is the opportunity to gain profit at the same time responsible to provide the best product and services through the adoption. 
12 out of 13 respondents were agreed towards this factor. One of the respondents from MAMPU responded:

“...Either organisation wants to adopt it or leave it, the decision is fixed where we need to adopt the Green IT due to Malaysia wants to be seen as the responsible developing country that plays its role with the nation".

Respondents from IBM Malaysia responded that:

“...We adopt green to the organisation first in each operation of IT, and then we will deliver to the customers".

Thus, the results show that the similarities between public and private sector through top management think are Green IT able to improve the overall performance at the same time being a benchmark in supporting Green Technology Policy, the adoption also one of the values for the organisation to be leading in the development of ICT technologies and provide the best solutions to the nation. Table 2 quotes the result.

Table 2

Summarize of organisational factor in Green IT adoption

\begin{tabular}{lll}
\hline Organisational factor criteria & Result from Public Company & $\begin{array}{l}\text { Result from Private } \\
\text { Company }\end{array}$ \\
\hline Responsible in developing country & “...Either organisation wants to & “... We adopt green to \\
Three stages of adoption in & adopt it or leave it, the decision is & the organisation first in \\
government: & fixed where we need to adopt the & each operation of IT, \\
• procurement side $\quad$ Green IT due to Malaysia wants to & and then we will deliver \\
• uses side & be seen as the responsible developing to the customers \\
- disposal side & country that plays its role with the & (Respondent from IBM \\
Forced by green technology policy & nation” (Respondent from MAMPU) & Malaysia) \\
Top management support & & \\
Improve the environmental & & \\
performance & & \\
Opportunity to gain profit & & \\
\hline
\end{tabular}

\section{Environment Factor}

For the environment factor, there are six criteria listed. First, reduce energy usage on the hardware of IT; second is implementing of cloud which could reduce electronic waste; third is preserving resources; fourth is responsibility leading to climate changes and commits to reducing the carbon footprint; fifth able to manage its environmental impact by adopting environmentally responsible emphasized in every department including operation, manufacturing, supply chain and sixth is specified all products meet the global green standard such as Restriction of Hazardous Substances (RoHS), Energy Star and Waste 
Electrical and Electronic Equipment Directive (WEEE). In this factor, 13 out of 13 stated this is the reason they are adopted Green IT. One of the KeTTHA respondent stated that:

"After Green IT was adopted in KeTTHA, it can be seen that reduction around $60 \%$ to $70 \%$ of energy".

This is supported by KeTTHA and Green Computing Initiative (2012) claimed that through the measurement via Power Usage Efficiency (PUE) tools, it can be seen that previous conventional technology, the new generation facility has enabled energy savings of $61.79 \%$. The similarities among five organisations: the reducing of energy consumption and carbon emission from the operation. One of the IBM Malaysia respondents claim that:

“...As we can see, companies need IT equipment for business matters connected with the other individual or organisation. Besides, IT hardware such as a PC, printer, storage and other equipment contained hazardous materials which produced lots of carbon emissions. From there, the company starts to produce all the equipment and technology that suits the environment and people concern".

Differences can be seen where the public sector is more on the using and disposing side where monitoring is easier than the private sector. The private sector needs to focus on every side of adoption, which is manufacturing, design, using and dispose of. It includes monitoring to achieve the mission in reducing the consumption of energy and decreasing the carbon emission. Table 3 simplifies the result.

\section{Business Opportunity Factor}

The criteria of business opportunity recorded sixth factor. First is producing products and services which can be commercialized to the internal and external of Malaysia. Second is high demand in a business opportunity. The third is the government more towards strategic collaborative engagement sharing the adoption knowledge among the agencies. Fourth is offers other private companies rebate and incentive to implement green technology project as highlighted by MyHijau (2017) that the government also pledged to deliver investment tax such as green investment tax allowance for companies that undertake green technology projects for business purpose, purchase green technology products, equipment and system that qualify as capital assets, and green income tax exemption for the company undertaking new green technology activities approved by GreenTech Malaysia. Fifth is depends on customer requirement and sixth is challenges and listening to the customer as a priority and start producing products. The result shows eight out of ten respondents were agreed towards this factor. One of the GreenTech respondent stated that:

“...Green IT generates an opportunity to an organisation especially for an organisation that produces products and services. GreenTech has produced and 
Table 3

Summarize of environmental factor in Green IT adoption

\begin{tabular}{|c|c|c|}
\hline $\begin{array}{l}\text { Environment factor } \\
\text { criteria }\end{array}$ & Result from Public Company & Result from Private Company \\
\hline $\begin{array}{l}\text { Reduce energy usage } \\
\text { on hardware of IT }\end{array}$ & $\begin{array}{l}\text { "After Green IT was adopted } \\
\text { in KeTTHA, it can be seen that } \\
\text { reduction around } 60 \% \text { to } 70 \% \text { of } \\
\text { energy" } \\
\text { (Respondent from KeTTHA) }\end{array}$ & $\begin{array}{l}\text { "...As we can see, companies need } \\
\text { IT equipment for business matters } \\
\text { connected with the other individual } \\
\text { or organisation. Besides, IT hardware } \\
\text { such as a PC, printer, storage and } \\
\text { other equipment contained hazardous } \\
\text { materials which produced lots of } \\
\text { carbon emissions. From there, the } \\
\text { company starts to produce all the } \\
\text { equipment and technology that suits } \\
\text { the environment and people concern" } \\
\text { (Respondent from IBM Malaysia) }\end{array}$ \\
\hline $\begin{array}{l}\text { Implementation of } \\
\text { Cloud }\end{array}$ & $\begin{array}{l}\text { The measurement via Power Usage } \\
\text { Efficiency (PUE) tools, it can be } \\
\text { seen that previous conventional } \\
\text { technology, the new generation } \\
\text { facility has enabled energy savings } \\
\text { of } 61.79 \% \text { (KeTTHA and Green } \\
\text { Computing Initiative,2012) }\end{array}$ & \\
\hline \multicolumn{3}{|l|}{ Preserve resource } \\
\hline \multicolumn{3}{|l|}{$\begin{array}{l}\text { Responsibility leading } \\
\text { to climate changes } \\
\text { and commits to reduce } \\
\text { carbon footprint. }\end{array}$} \\
\hline \multicolumn{3}{|l|}{$\begin{array}{l}\text { Adopting } \\
\text { environmentally } \\
\text { responsible }\end{array}$} \\
\hline $\begin{array}{l}\text { Meet the global green } \\
\text { standard }\end{array}$ & & \\
\hline
\end{tabular}

developed Green IT solution that calls as a thermodynamic solution by ourselves and we already commercialized to the external market. Therefore, today and the future, we have been moving forward by issuing standards, practices and provide advice to the European (EU) market".

A respondent from IBM Malaysia stated:

“... IBM Malaysia has adopted Green IT as a company is a leading company which the core business is to provide IT products, design of worldwide data centre, relocation and other services since the establishment of the company. Thus, the adoption of Green IT is a big opportunity to meet the customer requirement at the same time support the global mission to reduce the carbon footprint". 
Therefore, it is understood that when the organisation looking at the business opportunity side, organisations will see that the adoption of Green IT provides the best profit in end-to-end IT life. Moreover, through the offers by government sector such as financing loan, rebates, tax allowance, and other incentives, the organisation will be able to adopt Green IT as their initiative to face the challenges to meet the customer requirement and lastly fulfil the satisfaction from the products and services. Table 4 quotes the result.

\section{Cost factor}

First, initial costs of converting from conventional to Green IT technology is high, but reduction costs can be seen in the operational and provide a solid return to the business in the return of investment (ROI). This is supported by KeTTHA and Green Computing Initiative (2012) that Green IT adoption has reduced the overall expenditure of operating the public sector's backend IT facilities which currently stands at RM 120 million annually, compared to previously where cost electricity is expected to rise sharply over the next few years, amidst the planned end of gas subsidies coupled with the ever-growing IT facilities

Table 4

Summarize of business opportunity factor in Green IT adoption

\begin{tabular}{|c|c|c|}
\hline $\begin{array}{l}\text { Business opportunity } \\
\text { factor criteria }\end{array}$ & Result from Public Company & Result from Private Company \\
\hline $\begin{array}{l}\text { Producing products and } \\
\text { services which can be } \\
\text { commercialize to the } \\
\text { internal and external of } \\
\text { Malaysia }\end{array}$ & $\begin{array}{l}\text { "...Green IT generates an opportunity } \\
\text { to an organisation especially for an } \\
\text { organisation that produces products } \\
\text { and services. GreenTech has produced } \\
\text { and developed Green IT solution } \\
\text { that calls as a thermodynamic } \\
\text { solution by ourselves and we already } \\
\text { commercialized to the external market. } \\
\text { Therefore, today and the future, we } \\
\text { have been moving forward by issuing } \\
\text { standards, practices and provide } \\
\text { advice to the European (EU) market" } \\
\text { (Respondent from GreenTech) }\end{array}$ & $\begin{array}{l}\text { IBM Malaysia has adopted Green IT } \\
\text { as a company is a leading company } \\
\text { which the core business is to provide } \\
\text { IT products, design of worldwide } \\
\text { data centre, relocation and other } \\
\text { services since the establishment of } \\
\text { the company. Thus, the adoption } \\
\text { of Green IT is a big opportunity to } \\
\text { meet the customer requirement at } \\
\text { the same time support the global } \\
\text { mission to reduce the carbon } \\
\text { footprint". (Respondent from IBM } \\
\text { Malaysia) }\end{array}$ \\
\hline \multicolumn{3}{|l|}{ High demand } \\
\hline \multicolumn{3}{|l|}{$\begin{array}{l}\text { Government-strategic } \\
\text { collaborative among the } \\
\text { agencies }\end{array}$} \\
\hline \multicolumn{3}{|l|}{$\begin{array}{l}\text { Offers other private } \\
\text { companies rebate and } \\
\text { incentive }\end{array}$} \\
\hline $\begin{array}{l}\text { Customer requirement. } \\
\text { Customer as priority }\end{array}$ & & \\
\hline
\end{tabular}


requirement, the amount that government should pay is RM619 million for 2020. Second is reducing cost in term of energy consumption, human resources, and maintenance which decrease the cost up 30\% on maintenance cost. Third, the adoption of Green IT will cut the workforce from 50 to only a few workers compared to conventional. Reduce the costs in terms of employment, equipment, expertise, salaries, and many others. Fourth, the public sector is more geared towards performance and service, but private is more concerned with performance and profit. 14 out of 14 agreed cost is one of the factors in adopting Green IT. One respondent from MAMPU claimed that:

"...The development of Green IT is consuming high cost. But it will reduce costs over a long period due to the cost of startup Green IT is quite high. However, saving energy consumption has been greatly reduced where KeTTHA has savings of RM7000 to RM8000 per month when compared with conventional".

One of the respondents from HP Malaysia believes that:

“...In the development of new technology especially green technology, it utilizes a lot of initial costs and I believed that cost factor is one of the reason company adopt Green IT due to the profit that will gain from the production of a green product that generates from an expensive price on the market".

Based on the five organisations, it demonstrates that organisations believed converting to the Green IT requires high cost due to the certain high technologies with the green specification. Even though the cost of development is expensive, it proved that the development would help organisations toward efficiency, cost-saving, and increase the performance. However, as the private sector is looking for the profit, they believed that the adoption would show the impact based on the supporting of customers to their products. Thus, it shows that cost is a small issue to be compared with the return they obtain from the products and services. Table 5 quote the result.

As a conclusion, the result discussed above, shown that regulatory support factor and competitive pressure factor is not influence by the adoption of Green IT for the public and private sector. The reason is the respondents are not looking for regulatory and competitive in the adoption of Green IT. Plus, 11 out of 12 stated the regulatory support factor and 7 out of 11 clarified competitive are not relevant to adopt Green IT. The results rendered to the environmental factor, cost factor, organisational factor, technological factor, and business opportunity factor. It is not denying that the government sector is more toward performances of service to the society without thinking of competition among each other, whereas this study found that competitive pressure among private sector is not valid due to small market in Malaysia. 
Table 5

Summarize of cost factor in Green IT adoption

\begin{tabular}{|c|c|c|}
\hline Cost factor criteria & Result from Public Company & Result from Private Company \\
\hline $\begin{array}{l}\text { Initial costs is high but } \\
\text { reduction costs can be seen } \\
\text { in the operational }\end{array}$ & $\begin{array}{l}\text { "...The development of Green IT } \\
\text { is consuming high cost. But it will } \\
\text { reduce costs over a long period } \\
\text { due to the cost of startup Green } \\
\text { IT is quite high. However, saving } \\
\text { energy consumption has been greatly } \\
\text { reduced where KeTTHA has savings } \\
\text { of RM7000 to RM8000 per month } \\
\text { when compared with conventional" } \\
\text { (Respondent from MAMPU) }\end{array}$ & $\begin{array}{l}\text { "...In the development of new } \\
\text { technology especially green } \\
\text { technology, it utilizes a lot of initial } \\
\text { costs and I believed that cost factor } \\
\text { is one of the reason company adopt } \\
\text { Green IT due to the profit that will } \\
\text { gain from the production of a green } \\
\text { product that generates from an } \\
\text { expensive price on the market". } \\
\text { (Respondent from HP Malaysia) }\end{array}$ \\
\hline \multicolumn{3}{|l|}{$\begin{array}{l}\text { Reduce cost of: } \\
\text { energy consumption, } \\
\text { employment, equipment, } \\
\text { expertise, salaries. }\end{array}$} \\
\hline $\begin{array}{l}\text { in public sector } \\
\text { (performance and service) } \\
\text { in private sector } \\
\text { (performance and profit) }\end{array}$ & & \\
\hline
\end{tabular}

\section{The Proposed Framework in Implementing Green IT}

Results from the first objective to identify rendered factors are environmental factor, cost factor, organisational factor, technological factor, and business opportunity factor. The results lead to the second objective in proposing a framework on the factors rendered in Green IT adoption. As this study is based on a deductive approach which using the theoretical framework to help organize and direct the data analysis, the researcher analysed the data based on the research questions and research objectives at the same time using the theoretical framework as a guideline. Figure 2 shows the Proposed Framework in implementing Green IT.

Factors rendered in Green IT adoption

F1: Technological Factor

F2: Organisational Factor

F3: Environmental Factor

F4: Business Opportunity Factor

F5: Cost Factor

Figure 2. The proposed framework in implementing the Green IT 
Figure 2 shows significant in this study. This is related to the strategy to develop the proposed framework of Green IT adoption in Malaysia, starting from the literature review on the research objective. After the researcher gone through the literature reviews, the researcher constructed the theoretical framework which consists of seven factors of Green IT adoption as shown in Figure 1. Secondly, after the theoretical framework was constructed, the researcher collected the data through a semi-structured interview. The interviewer conducted to gain an in-depth understanding regarding the Green IT adoption at the same time to test the theoretical framework with five organisations that have their roles in the adoption of Green IT. Next, this study explained based on a deductive approach which using the theoretical framework to help organise and direct the data analysis, the researcher analysed the data using explanation building based on the research questions and research objectives at the same time using the theoretical framework as a guideline. Therefore, Figure 2 is an outcome of a theoretical framework that called a proposed framework which can be assisting policymaker, organisations such as public and private sector and other researchers to support Malaysia's pledge to reduce its Greenhouse Gas (GHG) emission intensity of Gross Domestic Product (GDP) by up to $45 \%$ by 2030 .

\section{CONCLUSION AND RECOMMENDATION}

This study aims to identify the factors rendered in the Green IT adoption in Malaysia and examine the factors that drive the adoption of Green IT in Malaysia. First, there are seven factors rendered in Green IT adoption in Malaysia (Figure 1). Two models are applied (TOE and DOI) to investigate the factors rendered in Green IT adoption and how the Green IT technology diffused in the organisations. Second, through the semi-structured interview, the result shows that the regulatory support factor and competitive pressure factor is not influential in the adoption of Green IT in the public and private sector. The reason is the respondents are not looking for regulatory and competitive in the adoption of Green IT. The results are more focus on the environmental factor, cost factor, organisational factor, technological factor, and business opportunity factor (Figure 2). It is not denying that the government sector is more toward performances of service to the society without thinking of competition among each other, whereas this study found that competitive pressure among the private sector is not valid due to the small market in Malaysia.

This study concluded that competitive pressure happens when it comes to market positioning and competitive pressure would not happen if the company is looking forward and focuses on the environmental responsibility to achieve the goal and improve the quality of business. In terms of the regulatory support factor, the researcher agreed that the respondents are not looking for the regulatory due Green IT in Malaysia is still new and the development of policy, regulation, enforcement is quite difficult. Thus, there are two parameters have been considered by the government body to encourage more organisation 
to adopt Green IT which is surveying numbers of the organisation have been adopted Green IT and start to prepare the development of Green IT policy and its enforcement with concern on several elements that would win both sectors.

Nonetheless, there are several benefits to the proposed framework. The proposed framework will go to the policymaker as a policymaker is acting as a funnel to gather information through consultation, research and to reduce and extract from the information, policy or set of policies that serve to promote what is the preferred course of action. From the new framework that been proposed, the policymaker able to see that regulatory support factor is petty looking by the organisations as Green IT policy does not exist yet in Malaysia. From the Green IT policy development, policymaker will be able to stringent the enforcement to the organisations to adopt the Green IT. Besides, from the proposed framework, MAMPU, KeTTHA and GreenTech will be able to develop the Green IT strategies and Green IT agendas to ensure that the Green IT could improve the adoption and well-spread implementation among the public and private sector. They also need to strengthen the activities which will lead the organisation to attract to adopt Green IT. Moreover, the proposed framework also provides the benefit to all private company including IT producers or service providers as a guideline for them to produce, designing, manufacturing Green IT products. The proposed framework also significance to the other researchers who willing to conduct further research. The proposed framework can be a guideline and reference for the researchers to conduct the other renewable energy sources such as solar computing as an innovative suggestion to the organisation where this initiative has been developed and produced by the other countries such as solar photovoltaic keyboard as Malaysia market about the solar photovoltaic in still low development.

\section{ACKNOWLEDGEMENT}

The author(s) extend their gratitude to Associate Professor Dr Chew Boon Cheong and Professor Ir Adi Saptari for guidance during this study research. This study is part of a dissertation which was submitted as partial fulfilment to meet requirements for the degree of Master at Universiti Teknikal Malaysia Melaka.

\section{REFERENCES}

Adnan, N., Nordin, S. M., Bahruddin, M. A., \& Tareq, A. H. (2019). A state-of-the-art review on facilitating sustainable agriculture through green fertilizer technology adoption: Assessing farmers behavior. Trends in Food Science \& Technology, 86, 439-452. https://doi.org/10.1016/j.tifs.2019.02.040

Asadi, S., Pourhashemi, S. O., Nilashi, M., Abdullah, R., Samad, S., Yadegaridehkordi, E., Aljojo, N., \& Razali, N. S. (2020). Investigating influence of green innovation on sustainability performance: A case on Malaysian hotel industry. Journal of cleaner production, 258, Article 120860. https://doi.org/10.1016/j. jclepro.2020.120860 
Asadi, S., Razak, A., Hussin, C., \& Mohamed, H. (2017). Telematics and informatics organizational research in the field of green IT: A systematic literature review from 2007 to 2016. Telematics and Informatics, 34(7), 1191-1249. https://doi.org/10.1016/j.tele.2017.05.009

Asadi, S., Yadegaridehkordi, E., Nilashi, M., \& Samad, S. (2019). Green information technology adoption: A systematic literature review. Journal of Soft Computing and Decision Support Systems, 6(3), 8-17.

Azis, S. S. A. (2021). Improving present-day energy savings among green building sector in Malaysia using benefit transfer approach: Cooling and lighting loads. Renewable and Sustainable Energy Reviews, 137, Article 110570. https://doi.org/10.1016/j.rser.2020.110570

Brinkmann, S. (2013). Qualitative interviewing. Oxford university press.

Chen, H., \& Ma, T. (2014) Technology adoption with limited foresight and uncertain technological learning. European Journal of Operational Research, 239(1), 266-275. https://doi.org/10.1016/j. ejor.2014.03.031

Cobos, L. M., Mejia, C., Ozturk, A. B., \& Wang, Y. (2016). A technology adoption and implementation process in an independent hotel chain. International Journal of Hospitality Management, 57, 93-105. https://doi. org/10.1016/j.ijhm.2016.06.005

Dalvi-Esfahani, M., Alaedini, Z., Nilashi, M., Samad, S., Asadi, S., \& Mohammadi, M. (2020). Students' green information technology behavior: Beliefs and personality traits. Journal of Cleaner Production, 257, Article 120406. https://doi.org/10.1016/j.jclepro.2020.120406

Dash, P., Pattnaik, S., \& Rath, B. (2016). Technology adoption process under internal uncertain environment in financial institutions: A case study with reference to public sector banks in India. International Journal of Applied Engineering Research, 11(1), 162-172.

De Zoysa, M., \& Wijayanayake, J. (2013). The influential factors of green IT adoption in data centres of Sri Lankan banks. Journal of Emerging Trends in Computing and Information Sciences, 4(12), 908-915.

Dibra, M. (2015). Rogers theory on diffusion of innovation-the most appropriate theoretical model in the study of factors influencing the integration of sustainability in tourism businesses. Procedia-Social and Behavioral Science, 195, 1453-1462. https://doi.org/10.1016/j.sbspro.2015.06.443

Esfahani, M. D., Rahman, A. A., \& Zakaria, N. H. (2015). Green IT/IS adoption as corporate ecological responsiveness: An academic literature review. Journal of Soft Computing and Decision Support Systems, 2(1), 35-43.

Fernando, Y., \& Wah, W. X. (2017). The impact of eco-innovation drivers on environmental performance: Empirical results from the green technology sector in Malaysia. Sustainable Production and Consumption, 12, 27-43. https://doi.org/10.1016/j.spc.2017.05.002

Gazzola, P., Del Campo, A. G., \& Onyango, V. (2019). Going green vs going smart for sustainable development: Quo vadis? Journal of Cleaner Production, 214, 881-892. https://doi.org/10.1016/j.jclepro.2018.12.234

GreenTech Malaysia. (2011). Green ICT - The Malaysia's perspectives green technology corporation Malaysia. Retrieved June 10, 2019, from https://home.jeita.or.jp/greenit-pc/activity/asia/file/Green_ICT__The_ Malaysias_Perspectives.pdf 
GreenTech Malaysia. (2013). National green technology policy: Cleantech made in Germany industry symposium Malaysian green technology corporation green technology corporation Malaysia. Retrieved June 10, 2019, from http://www.gtai.de/GTAI/Content/EN/Meta/Events/Invest/2013/Reviews/ Powerhouse/Downloads/presentation-130409-malaysia-ismail-malaysian-green-tech-corp.pdf?v=2

Guest, G., Bunce, A., \& Johnson, L. (2006). How many interviews are enough? An experiment with data saturation and variability. Field Methods, 18(1), 59-82. https://doi.org/10.1016/j.jclepro.2018.12.234

Gupta, S., \& Kumar, V. (2012). Sustainability as corporate culture of a brand for superior performance. Journal of World Business, 48(3), 311-320. https://doi.org/10.1016/j.jwb.2012.07.015

Junior, B. A., Majid, M. A., \& Romli, A. (2018). Green information technology for sustainability elicitation in government-based organisations: An exploratory case study. International Journal of Sustainable Society, 10(1), 20-41. https://doi.org/10.1504/IJSSOC.2018.092648

Kasbun, R., Adnan, A. S., Khalid, N., \& Jaafar, H. (2016). Green ICT practices and challenges: Electronic waste disposals steps awareness in overcoming environmental erosion. International Conference on Information Technology and Multimedia 2016, 1, 34-40.

KeTTHA \& Green Computing Initiative. (2012). The green data centre: Achieving the true potential of sustainable computing. A Joint Research Report by the Ministry of Energy, Green Technology and Water Malaysia and The Green Computing Initiative. Putrajaya, Malaysia: Author.

Khan, H., \& Faisal, M. N. (2015). A grey-based approach for ERP vendor selection in small and medium enterprises in Qatar. International Journal of Business Information System,19(4), 465-487. https://doi. org/10.1504/IJBIS.2015.070205

Lee, S. G., Trimi, S., \& Kim, C. (2013). The impact of cultural differences on technology adoption. Journal of World Business, 48(1), 20-29. https://doi.org/10.1016/j.jwb.2012.06.003

Letlonkane, L., \& Mavetera, N. (2014). An investigation of factors that inform green IT practices in the North West Provincial Government of South Africa. Mediterranean Journal of Social Sciences, 5(20), Article 163. https://doi.org/10.5901/mjss.2014.v5n20p163

Malik, S. A., \& Ayop, A. R. (2020). Solar energy technology: Knowledge, awareness, and acceptance of B40 households in one district of Malaysia towards government initiatives. Technology in Society, 63, Article 101416. https://doi.org/10.1016/j.techsoc.2020.101416

Managi, S., Hibiki, A., \& Shimane, T. (2014). Efficiency of technology adoption: A case study in wastetreatment technology. Resource and Energy Economics, 36(2), 586-600. https://doi.org/10.1016/j. reseneeco.2013.09.002

Martínez-Mesa, J., González-Chica, D. A., Duquia, R. P., Bonamigo, R. R., \& Bastos, J. L. (2016). Sampling: How to select participants in my research study? Anais brasileiros de dermatologia, 91(3), 326-330. https://doi.org/10.1590/abd1806-4841.20165254.

Mergel, I., \& Bretschneider, S. I. (2013). A three stage adoption process for social media use in government. Public Administration Review, 73(3), 390-400. https://doi.org/10.1111/puar.12021

Ministry of Energy Green Technology and Water. (2017). Green Technology Master Plan Malaysia 2017 2030. Putrajaya, Malaysia: Author. 
Ministry of Energy Green Technology and Water Malaysia. (2009). National Green Technology Policy (1st Ed.). Putrajaya, Malaysia: Author.

Mohammed, M. A., Muhammed, D. A., \& Abdullah, J. M. (2015). Green computing beyond the traditional ways. International Journal of Multidisciplinary and Current Research, 3, 787-792.

Molla, A., \& Abareshi, V. C. A. (2014). Green IT beliefs and pro-environmental IT practices among IT professionals. Information Technology \& People, 27(2), 129-154. https://doi.org/10.1108/ITP-10-20120109

Murugesan, S., \& Gangadharan, G. R. (2012). Harnessing green IT: Principles and practices. Wiley Publishing.

MyHijau. (2017). Green incentive. Retrieved July 10, 2019, from https://www.myhijau.my/green-incentives/

Ojo, A. O., Raman, M., \& Downe, A. G. (2019). Toward green computing practices: A Malaysian study of green belief and attitude among information technology professionals. Journal of Cleaner Production, 224, 246-255. https://doi.org/10.1016/j.jclepro.2019.03.237

Rad, M. S., Nilashi, M., \& Dahlan, H. M. (2018). Information technology adoption: A review of the literature and classification. Universal Access in the Information Society, 17(2), 361-390. https://doi.org/10.1007/ s10209-017-0534-Z

Rahim, R. E. A., \& Rahman, A. (2013). Resource-based framework of green IT capability toward firms' competitive advantage. In Proceedings of the 17th Pacific Asia Conference on Information System (pp. 18-22). Association for Information Systems.

Saha, B. (2014). Green computing. International Journal of Computer Trends and Technology (IJCTT), 14(2), 46-50.

Saunders, M., Lewis, P., \& Thornhill, R. (2016). Research methods for business student (7th Ed.). Pearson Education Ltd.

Shameer, A. P., Haseeb, V. V., \& Mol, V. K. M. (2015). Green approach for reducing energy consumption-A case study report. International Journal, 5(1), 1-10.

Shibly, A. (2015). Green computing - Emerging issues in IT. ResearchGate, 1-15. https://doi.org/10.13140/ RG.2.1.1729.4248

Simon, C. (2013). Driving new technology adoption in South Africa's energy sector. Retrieved July 10, 2019, from http://pubs.iied.org/pdfs/17178IIED.pdf

Singh, J. V., \& Vatta, S. (2016). Green computing: Eco friendly technology. International Journal of Engineering Research and General Science, 4(1), 280-283.

Taruna, S., Singh, P., \& Joshi, S. (2014). Green computing in developed and developing countries. International Journal in Foundations of Computer Science \& Technology (IJFCST), 4(3).

Unhelkar, B. (2016). Green IT strategies and applications: Using environmental intelligence. CRC Press.

Zailani, S., Govindan, K., Iranmanesh, M., Shaharudin, M. R., \& Chong, Y. S. (2015). Green innovation adoption in automotive supply chain: The Malaysian case. Journal of Cleaner Production, 108, 11151122. https://doi.org/10.1016/j.jclepro.2015.06.039 
Zhang, Y., Sun, J., Yang, Z., \& Wang, Y. (2020). Critical success factors of green innovation: Technology, organization and environment readiness. Journal of Cleaner Production, 264, Article 121701. https:// doi.org/10.1016/j.jclepro.2020.121701 